\title{
REMEMBERING THE FORGOTTEN WAR Origins of the Korean War Film and Its Development during Hallyu
}

\author{
Joel David \\ Inha University \\ joeldavid@inha.ac.kr
}

\begin{abstract}
As the Cold War proxy conflict that provided a happy ending for the Western alliance that fought for the South Korean side, the Korean War became a recurrent and idealized subject for American film productions. A generally overlooked trend, however, is the fact that Korea itself subsequently embarked on a reflective series of cinematic discourses on the war and its aftermath, during the period when the country's popular culture (eventually dubbed hallyu) began to attract foreign interest. The contrast between post-war Hollywood images and fairly contemporary Korean output regarding the topic provides a starting point for studying issues pertaining to trauma, history, power, knowledge, and difference.
\end{abstract}

\section{Keywords}

Hollywood, New Korean Cinema, war-film genre, world cinema

\begin{abstract}
About the Author
Joel David is Professor for Cultural Studies at Inha University in Korea and winner of the Filipino Arts \& Cinema International Festival's Gawad Lingap Sining (culture-nurturing) lifeachievement award in 2016. He had formerly taught at the University of the Philippines Film Institute, where he was founding Director. He holds a Ph.D. in Cinema Studies at New York University and maintains an archival blog titled Amauteurish! (at https://amauteurish.com). He has written a number of books on Philippine cinema, and his articles have appeared in (among others) GLQ, Asian Journal of Women's Studies, International Journal of Asian Studies, Plaridel, Manila Review, and Kyoto University's Asian Studies. His interests include genders and sexualities, Orientalism, narrative, and new media.
\end{abstract}


The war-movie genre, which originated in and developed in Western cinema, specifically Hollywood, may be seen to have its counterparts in countries that experienced similar traumas. In localizing and periodizing this genre in terms of one country, Korea, specifically the so-called "police action" that started in 1950, escalated into a series of full-scale battles, and ended in a truce in 1953, Hollywood production will still necessarily be part of the picture, since the entity that represented the West in this proxy Cold-War conflict was the US. The complex arguments that have been propounded regarding the possible causes of the war as well as the implications of the still-unresolved conflict as it pertains to Korean reunification, regional stability, the sustainability of the socialist state system, and several others - all these will be relevant to the present article only in so far as they arise in the movies that have been available for consideration.

One further limitation is that, in speaking of war movies as a genre, we refer to fiction films, whether or not based on actual events: in short, theatrical features rather than documentaries. Hence this study will cover the production of significant feature films on the Korean War, with "Korea" understood, following general practice, as referring to the Republic of Korea, or South Korea. The rationale favoring this circumscription is that in terms of global film awareness, what passes among observers for what we term as "Korea," most significantly hallyu or the Korean popular culture wave, is actually South Korean. My interest in the topic derives from my observation of Korean War film releases during the hallyu period, or roughly since the 1990s. In returning to Hollywood representations of the Korean War, I realized that not only were the Hollywood releases misunderstood as belonging to the earlier (i.e., pre-Vietnam War film) tradition, but that the war film's historical development needs to be revised because of the contributions of Korean producers to the genre during its hallyu-era revival.

Korea studies scholar Craig S. Coleman described the Korean War as the point in which Americans awakened to Korea (77-78), with the earlier years of the twentieth century relegated to the country's self-description as the "hermit kingdom" (6-7). This earlier period, from 1910 to 1945 , actually involved a different kind of war: a protracted resistance to Japanese occupation, with an exile government set up in China. If this sounds similar to the experience of Filipinos in relation to the American occupation, that would be because the two imperialist adventures were directly linked. An agreement between the US and Japan, called the Taft-Katsura Memorandum of 1905, effectively ceded Korea to the Japanese and the Philippines to the US (Esthus 46-51; see also Coleman 42).

This study will begin by working out a redefinition of the war film as a genre, primarily in order to avoid confusion with the several other types of films on the Korean War. It will then look at Hollywood feature productions with the war as

Kritika Kultura 28 (2017): -146

(C) Ateneo de Manila University

$<$ http://journals.ateneo.edu/ojs/kk/> 
their coverage, up to the point where primary treatments (as opposed to incidental references) ended by the end of the 1970s. Then it will focus on the revitalization of the Korean War as feature film material, this time in Korean cinema-a stillongoing and necessarily open-ended phenomenon.

\section{FULL SCALE}

An effective reference for the first part of this study would be Robert J. Lentz's Korean War Filmography. It supplies filmographic data and commentary for, as the subtitle mentions, ninety-one English-language features, and includes extensive appendices providing a chronology of the titles, their listing according to producer and distributor, their classification in terms of propagandistic content as well as thematic elements, and more relevant to marginal interests, listings of films with incidental references to the Korean War, South Korean productions, and documentaries (reminiscent of a project by Linda Dittmar and Gene Michaud, titled From Hanoi to Hollywood).

If we add the 91 English-language films in Lentz's book to the 27 that he described as providing "incidental reference" to the war, we would come up with 118 titles by 2000, the cut-off year of his research. This would render his study more reliable than standard digital-era sources, including the Internet Movie Database or IMDB. A keyword search at IMDB specifying "Korean War" (with English as language) would yield a slightly larger number of titles, though many of these would raise the question of just how incidental is "incidental." For the purpose of building on Lentz's volume, I compiled the IMDB titles separately and listed the ones that have appeared since the new millennium.

Table 1. List of US Films After 2000 That Reference the Korean War

\begin{tabular}{lclll}
\hline Primary Title & Year & Type & Filmmaker(s) & Performer(s) \\
\hline Big Fish & 2003 & Feature & Tim Burton & Ewan McGregor \\
Walk the Line & 2005 & Feature & James Mangold & $\begin{array}{l}\text { Joaquin Phoenix, } \\
\text { Reese Witherspoon }\end{array}$ \\
The Borinqueneers & 2007 & Feature & $\begin{array}{l}\text { Noemi Figueroa Soulet } \\
\text { \& Raquel Ortiz }\end{array}$ & Hector Elizondo \\
Tie a Yellow Ribbon & 2007 & TV & Joy Dietrich & Kim Jiang \\
& & Feature & &
\end{tabular}




\begin{tabular}{|c|c|c|c|c|}
\hline As You Were & 2008 & $\begin{array}{l}\text { Short } \\
\text { Feature }\end{array}$ & $\begin{array}{l}\text { Benjamin J. } \\
\text { Bumgarner }\end{array}$ & $\begin{array}{l}\text { Joe Heil, } \\
\text { Kim Su Hyun }\end{array}$ \\
\hline Gran Torino & 2008 & Feature & Clint Eastwood & Clint Eastwood \\
\hline The Orphan & 2008 & Feature & Bryan Nest & Will Chung \\
\hline Grace & 2011 & $\begin{array}{l}\text { Short } \\
\text { Feature }\end{array}$ & Roth Rind & $\begin{array}{l}\text { Donn Bradley, } \\
\text { Peter Kim }\end{array}$ \\
\hline Retreat! & 2012 & Feature & Scott Slone & $\begin{array}{l}\text { Geoffrey Lewis, } \\
\text { Richard Roundtree }\end{array}$ \\
\hline $\begin{array}{l}100 \text { Miles to } \\
\text { Lordsburg }\end{array}$ & 2015 & $\begin{array}{l}\text { Short } \\
\text { Feature }\end{array}$ & Karen Borger & Brian D. Mason \\
\hline
\end{tabular}

Source: Internet Movie Database (URL <http://www.imdb.com>).

As we can see from the list (and as supplemented by the plot summaries on IMDB), the only way to view Korean War scenes realistically in a currentmillennium Western movie is when the film is a period production, set in a distant territory over six decades in the past; that, or a contemporary character, necessarily elderly, experiences a dream or a flashback, usually as a traumatic response to some seemingly innocuous stimulus. ${ }^{1}$ The generation of Koreans who were directly affected by the war, separated from one another by the one hundred twenty-mile demilitarized zone, is rapidly dwindling, and along with them the desire for reunification, if we were to go by the results of surveys of the current generation of South Koreans. Most of the latter are aware of the initial difficulties experienced by Germany when the Federal Republic agreed to effectively absorb the less prosperous socialist Democratic Republic in 1990.

Lentz's book is significant in another way: in most other available Western studies on the war-film genre, movies on the Korean War are rarely tackled. This would have something to do with the fact that the Korean War film has a liminal status, one that I will be elaborating on later. For now, we have to explain first what a war film is, and why we run into problems when talking about films on the Korean War. When Vladimir Lenin declared that film would be the medium that the then newly founded Soviet Union would be using to promote socialism, he was actually, perhaps unconsciously, mirroring a cultural-policy declaration made by the US Secretary of the Interior, Dean Conant Worcester, regarding the process of enhancing the colonization of the Philippines (Deocampo 29-64).

The symbiotic relationship between film and the so-called modern wars of the twentieth century is something that is often overlooked in studies of the medium. 
Both processes, film and war, involve significant investments, occasionally with the partial or full subsidy of the state; they require the participation of individuals with talent and training; they deploy a collective of workers, all of whom should be preferably infused with a sense of mission; and at least during the celluloid as well as the classical-warfare era, they involve the operation of complex, expensive, and heavy machinery-which means that these workers will mostly have to be male, with the women in their lives relegated to either domestic tasks or to symbolic ideals as either the motherland in one case or the movie star in the other.

For this reason it made total sense for celluloid-era films to excel in the depiction of modern wars, although we could also turn that statement around and say that the wars delimited what films could depict, at least initially (Slocum 1-3). Pretwentieth-century conflicts, per the prescription of film scholars, would not be counted as war films, but rather as period movies with battle scenes. Scenes that looked at social or political tensions, even those that portrayed armed clashes, may be gangster films or social-problem films; some films that are set in historical war situations may in fact be melodramas or even comedies.

The generic element that "marks" the war film is the extended combat scene (Neale 23-24). Once more, we take note of the fact that any popular genre differs from traditional literary forms (e.g. poetry or drama) in the sense that the former's definition necessarily keeps shifting. For now, all we could maintain is that combat scenes in a war film tend to recur, and that there will be moments of relief where (usually) dramatic issues among the characters may be played out. In this sense the genre may be reminiscent of other similar types of films where specialized "numbers" alternate with plot: where the numbers are song-and-dance executions, these will be musicals; where they are sexual encounters or displays, these will be pornography; where they are combat mayhem, these will be war films. To minimize confusion when we speak of films on the Korean War that are not necessarily war films, the term "combat film" to mean "war film" in film-genre discourse will be used in this article.

\section{FORGOTTEN WAR}

To elaborate on the problem, when we talk about "Korean War films," we can see how unstable such a generic definition is. Many Korean War films will be war films as defined in film scholarship, in the sense that they will have combat scenes focused on either the entire war or on specific battles. However, many other Korean films require an awareness, if not the memory, of the war in order to be fully appreciated. In fact, we can proceed from the insight that since the 1950s, the 
existence of the entire Korean peninsula, specifically its division into two countries, is contingent on a war that still has to be resolved, with the two entities prepared for the possibility that conflicts might resume at any time, with or without warning. In this sense, then, anything from either Korean country is the result of a war situation, and therefore any Korean film is, in a profound historical sense, a Korean War film, and may be read accordingly.

On the other hand, within the particular terms of focusing on the reality of an unfinished Korean War, any film on the topic, whether Korean or foreign, whether a combat film or any other type of genre, can be considered either a Korean War film, or a film directly or incidentally about the Korean War. For this purpose I would propose that we not insist on the presence of combat scenes when we talk about Korean War films, since over six decades of the still-ongoing Korean War have transpired without any actual combat, except for the rare exchange of bullets or cannon fire. What reinforces this argument is the fact that, from the perspective of foreign cinema studies, non-Korean combat films that have the Korean War as their primary coverage do not figure out as extensively as other types of combat films, whether in terms of number of productions or of scholarly studies. From the perspective of the US, the war in Korea came between two more impactful events; as Thomas Doherty puts it:

Back on American shores, another kind of bleeding has come to obscure the focus. Always the cultural legacy of the Vietnam War filters and fogs the images of World War II. Vietnam, itself so much a product of the mythos of Hollywood's war, has discredited its predecessor [WWII, not the Korean War] and the medium that projected it. (3)

World War II was understandably being celebrated long after the Korean War was over, and depictions of events in it came not just from Hollywood but also from the many countries in Europe and Asia that were directly affected by the perceived aggression of the Axis powers and resistance of the Allied forces. The Korean War was similarly successful for the United Nations alliance that countered the North Koreans' incursion into South Korea, but the actual antagonist, the USSR, was in fact a former ally of the US and Western Europe during World War II, and beyond the Soviet Union and (subsequently) China, no other socialist-bloc countries got involved.

After the Korean War and the French pullout from Indochina, the US embarked on its military adventure in Vietnam, and here Hollywood production was initially even more silent, since the American population regarded the exercise as unjustifiable in terms of the loss of lives, especially on the Vietnamese side, and found the anti-Communist ideological line that had worked in the Korean War a flimsy pretext for colonial expansion. Hence all that could be produced regarding 
the US incursion in Vietnam were the expected gung-ho John Wayne starrers and a handful of critical independent documentaries, plus a subgenre of horror films, called the Blood Island exploitation movies, produced in the Philippines (Lim 23-45). ${ }^{2}$ By 1975, the US had to concede defeat to the North Vietnamese army, and this opened the floodgates to a series of works that epitomized some of the best moments of New American Cinema, alongside the usual escapist fare still headlined by an indie talent, Sylvester Stallone's Rambo (Sklar 335-37).

From this explanation, it should not be surprising that extensive combat-film studies tended to overlook the Korean War, mostly relegating the event to a few paragraphs, a chapter at the most. ${ }^{3}$ This oversight is being redressed by a few volumes, most of them difficult to access, that focus exclusively on films on the Korean War. ${ }^{4}$ Yet if we look at the several junctions where the combat film, global cinema, and discourses on the Korean War overlap, we can see that the still-current critical downgrading of movies on the Korean War is undeserved and calls for a reconsideration, along with the redefinition of the Korean War film mentioned earlier.

\section{UNEASE IN THE MORNING CALM}

In discussing the problematic representation of the Korean War in Hollywood cinema, the significance of Robert Altman's MASH (1970) cannot be overlooked (see Figure 1). When it came out, it was immediately recognized and hailed as a potent metaphor for the US involvement in Vietnam, with a slew of critics' prizes topped by the Cannes Film Festival's Palme d'Or, not to mention a long-running and similarly highly acclaimed TV series that ran for over a decade. Like the Philippineset Blood Island movies, MASH was intended to depict the absurdities of Americans operating in an alien territory where the natives were, to put it mildly, resentful of their presence. Unlike the Blood Island films, however, and like another film adaptation of a novel, Joseph Heller's Catch-22 (1961), filmed (by Mike Nichols) the same year as $M A S H$, these post-Classical Hollywood and New American Cinema entries were not only deliberately referencing Vietnam; they were also set in the earlier wars that the US had participated in-Catch-22 in World War II and MASH in the Korean War.

To be fair, the impression that Korean War combat films partook of the Manichean sensibilities of the World War II films is understandable, especially if we look at the majority of the early output of both Hollywood and Korea. Since the Korean War was also not as globally consequential as World War II, a large proportion of the Hollywood productions were what Robert Lentz described as medium-to-low

Kritika Kultura 28 (2017): -146

(C) Ateneo de Manila University

$<$ http://journals.ateneo.edu/ojs/kk/> 


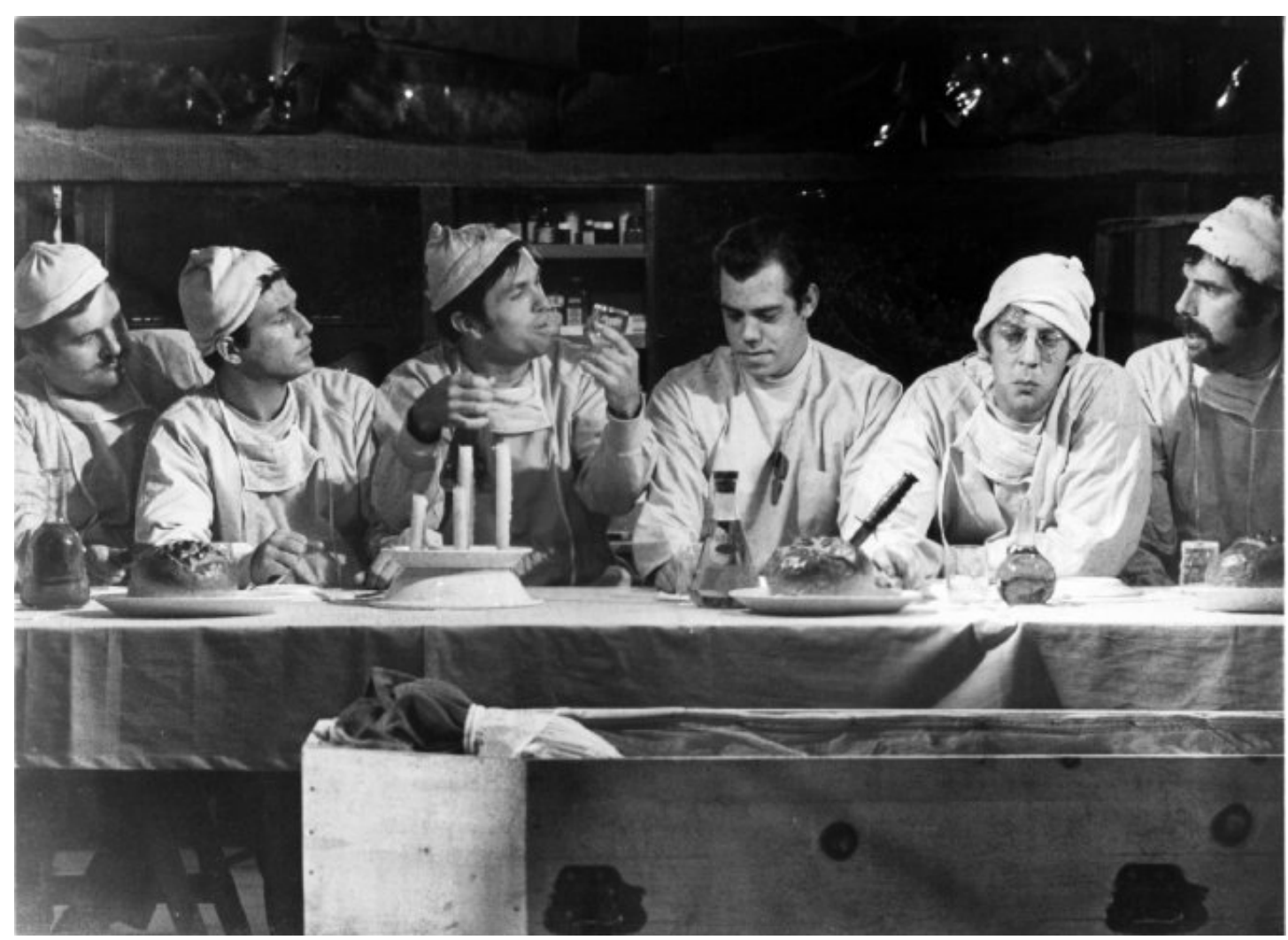

Figure 1. Last Supper parody in Robert Altman's MASH (1970). Publicity still from Aspen, Ingo Preminger, and Twentieth Century Fox.

in terms of historical accuracy, and medium-to-high in their propaganda level (430-33). One might safely say that American producers subsequently regarded their investments as better spent on projects that covered the Vietnam War-as demonstrated in Francis Ford Coppola's Apocalypse Now (1979), among several other highly regarded epics. Even World War II continues to show up in prestige presentations, including major undertakings during the last few decades by celebrated American auteurs such as Terrence Malick, Steven Spielberg, and Clint Eastwood. ${ }^{5}$

On the other hand, a vital turn in film appreciation, one that ultimately led to the collapse of Classical Hollywood and its replacement by the New American Cinema in the late 196os, was already starting to take place in France during the 1950s, when the Korean War combat films were being churned out. The Cahiers $d u$ Cinéma group of critics disparaged what they called the "cinema of quality" of 
Classical Hollywood (and, by extension, their own copycat French practitioners) and directed attention to precisely the kinds of movies that critics and awards groups preferred to overlook: the B-film productions. They identified film directors as the central artistic intelligence behind the creativity that could flourish only in minimally supervised low-budget projects, and one of their favorite auteurs was Samuel Fuller, who directed a couple of Korean War combat movies in 1951, Fixed Bayonets! and The Steel Helmet. Curiously, it was the smaller-budgeted Fuller film that depicted the traumatic consequences of the Korean War, Shock Corridor (1963), that met with raves from his European admirers and is now regarded as his masterpiece (see Figure 2).

Shock Corridor portrayed a war veteran who, as a result of brainwashing by

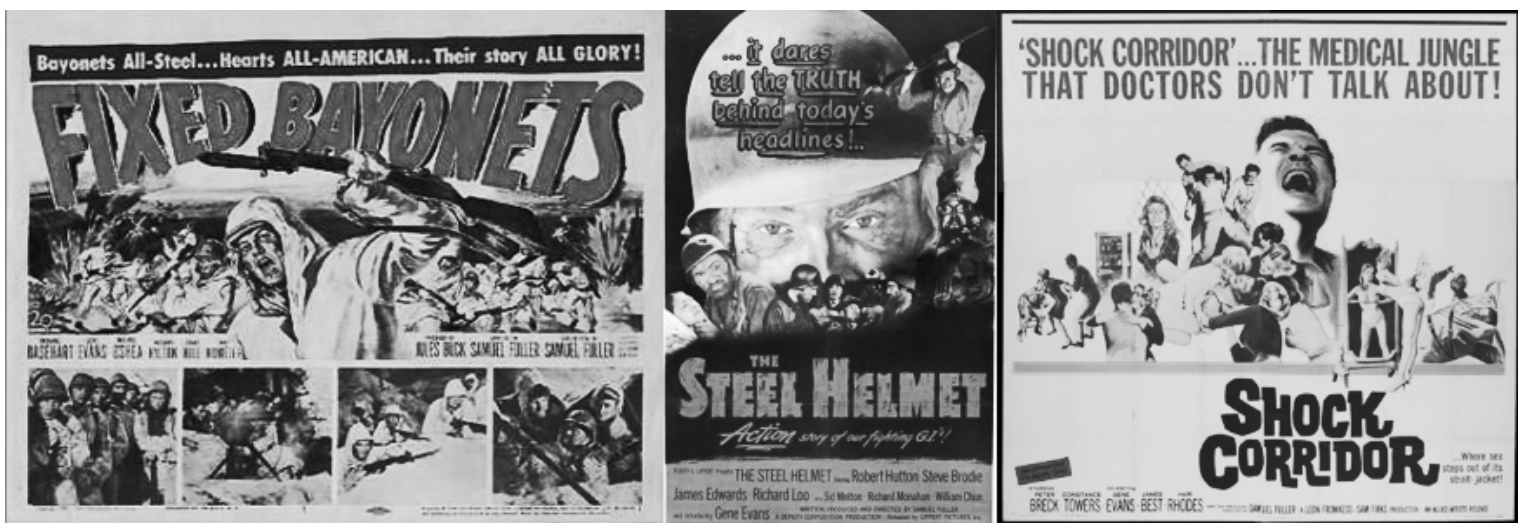

Figure 2. Samuel Fuller's Korean War-related films, left to right: Fixed Bayonets! (1951), The Steel Helmet (1951), and Shock Corridor (1963). Publicity layout from Twentieth Century Fox; Deputy Corp.; and F \& F Productions and Allied Artists Pictures respectively.

the enemy, turned into a Communist sympathizer, was rejected by his father, and retreated into a fantasy world where he assumes the identity of a Confederate general. This narrative treatment in fact led to a subgenre of the combat film that had never been explored as intensively as the "regular" combat film: the prisonerof-war or POW film. What distinguished the Korean-War POW movie was that, unlike World War II escape narratives such as Billy Wilder's Stalag 17 (1953), these interrogated the effects of the Korean War after the return of combatants from their tour of duty. The underlying theme in what we may more fully term the paranoid Korean-War POW film is that the returnee brings the memory of the war home with (the always masculine) him, and in doing so enables the people around him, who would have otherwise been shielded by the proxy nature of the conflict, to see how horrific the experience had been. 
The standard paranoid-POW title is John Frankenheimer's The Manchurian Candidate (1962), which posited that not just trauma, but also overseas ideological intervention, can result from exposure to the enemy (see Figure 3). The brainwashing premise here is even more unlikely than the one depicted in Shock Corridor, but the movie's more paranoid reconfiguration of Cold War troubles as comprising a hidden alliance between extremists in both capitalist and socialist systems, up against the best intentions of liberal democrats, was lent an air of credibility in its barely concealed critical reference to the anti-Communist witch-hunts instigated by US Senator Joseph McCarthy; so much so that just as McCarthyism became synonymous with right-wing rabble-rousing by politicians with careerist motives, so has the term "Manchurian candidate" come to refer to a public figure who underhandedly uses her or his stature to promote the interests of a hostile foreign government.

With the paranoid-POW films we can see how ambiguity and cynicism predated $M A S H$ and the succeeding Vietnam War combat films. In fact it would even be problematic to describe The Manchurian Candidate as a Korean War film, since

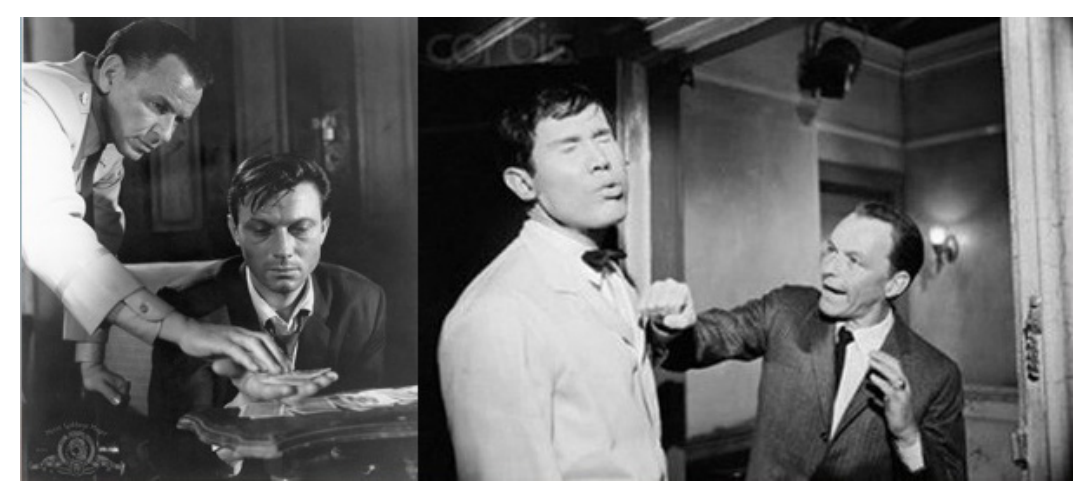

Figure 3. Major Bennett Marco (Frank Sinatra) counsels Raymond Shaw (Laurence Harvey), as the titular brainwashed assassin; and overpowers the martial arts-wielding Chunjin (Henry Silva), in John Frankenheimer's The Manchurian Candidate (1962). Publicity stills from M.C. Productions.

the most prominent Korean character turns out to be a South Korean officer named Chunjin, who secretly assists the ruthless socialist alliance among North Koreans, Chinese, and Russians. Yet what finally sets this film apart from previous combat films is the manner in which Orientalism is evoked. The World War II films set in the Pacific theater, as well as standard Korean War combat movies, portray Westerners and their Asian allies against a horde that is wholly East Asian in 
appearance; in The Manchurian Candidate, the brainwashing session (tantamount to a slow-torture episode) provides a mix of Asian and Caucasian observers and participants. This liberal gesture allows certain white characters (who, in the plot, will later be mingling with Americans in the US) to be demonized in alliance with the McCarthy-like figure in the narrative.

\section{END OF ORIENTALISM}

This shift in the depiction of Orientals was a process that can be traced ironically to the vanquished forces of World War II. If any awkwardness could be perceived in the racial balance between the opposing forces, it lay in the composition of the Allied countries, since on the other side, the Germans and the Italians teamed up, so to speak, with the Japanese. The irony of course is that the Europeans in this group actually invoked racist language and imagery against their own Jewish populations. Nevertheless by the end of the war, and the start of the Cold War, both sides in the new conflict were ready to accuse one or the other of racist treatment of their own internal populations. The US was especially vulnerable, since African Americans might have already been freed by then from slavery, but still did not have the full complement of civil rights that European-descended US citizens enjoyed. (Ellen D. $\mathrm{Wu}$ traces this process of selectively excluding Asians from racial discrimination, as a way of justifying the maintenance of harsher policies for other minority groups, in The Color of Success.)

In discussing the Cold War, scholars tend to focus on US President Harry S. Truman's 1947 speech requesting congressional allocation to address the unstable political conditions in Greece and Turkey, using the logic of containment-i.e., that without US intervention, the Soviet Union would be able to effectively export Communism to these territories and thereby expand the socialist bloc. Yet Christina Klein, in taking a fresh perspective on so-called middlebrow popular culture of the 1950s, has argued that the US State Department, tasked with carrying out this global policy of containment, complemented it with another policy: that of a specific type of racial integration. Since the department's jurisdiction did not include the implementation of policies that would directly affect the local American population, it attempted to counter its Cold War enemies' accusation of Western racism by providing support and encouragement for progressive American artists, some of whom had former affiliations with the US Communist Party, to create material that would break down racial differences between Americans and Asians (Klein 21-28). 
These works were not plentiful, but they were ambitious and influential, and have endured in popularity even to the present. Many of them were typically drawn from the humanist novels and accounts of authors such as Pearl S. Buck and especially James A. Michener. Any novel adjudged as pro-US though anti-Orientalist would first be adapted into a Broadway musical, often with the successful team of Richard Rodgers and Oscar Hammerstein II providing songs, before being turned into a major roadshow movie production. Some of these Rodgers and Hammerstein filmed musicals include Walter Lang's The King and I (1956), from Margaret Langdon's biographical novel Anna and the King of Siam (1944); Joshua Logan's South Pacific (1958), from Michener's Tales of the South Pacific (1947); and Henry Koster's Flower Drum Song (1961), from the eponymous 1957 novel by C. Y. Lee.

Klein regards the American decision to grant statehood to Hawai'i as the culmination of this semi-official policy (243-52). I would prefer to modify this insight by pointing out that the US had already displayed an attitude of deference to Oriental peoples in its handling of the surrender of Japan. The magniloquent egocentricity of the Supreme Commander of the Southwest Pacific Area, Douglas MacArthur, resulted in his decision to exempt from war-crimes prosecution the Japanese then-head of state, Emperor Hirohito (over the objections of a few Allied officials), and led to the unprecedented spectacle of both of them greeting each other as equals (Manchester 575-78).

In 1957, a year before he adapted James Michener's Tales of the South Pacific to film, Joshua Logan undertook another Michener novel, the semi-autobiographical Sayonara, written in 1954 (see Figure 4). Marlon Brando played a US Army serviceman who is stationed in Japan and falls in love with a native woman; Major Lloyd "Ace" Gruver, his character, had completed his assignment to Korea in 1952, fighting in the Korean War, and would be awaiting his return to the US mainland. The significance of the war in relation to the film's narrative concerns is expressed by Gina Marchetti thus:

Although Sayonara asks to be read as an antiwar film, the reality of the Korean War and the controversy it generated are placed on the back burner ... . Gruver, apparently disillusioned with American involvement in Korea, mumbles that one of the pilots he shot down that day had a "face." This is the film's only real reference to the actual morality of war, and . . . the film instead chooses to quietly question war in general by allowing Gruver to comment on the humanity of his enemy. (128-29)

Marchetti argues that, despite its critique of racism (traceable via Gruver's progression from anti-Asian bigot, to curious witness to the interracial marriage of his subordinate, to outright romantic involvement, to the point of matrimony, 
with a Japanese woman), Sayonara nevertheless falls back on the gendering of intercultural roles based on racial and economic differences: in the romantic relationships in the film, the white and victorious Americans are male while the "yellow" and defeated Japanese are female. ${ }^{6}$ More significantly, the costs of war are alleged to have resulted in losses to both sides, i.e. the Americans suffered and, consequentially, that implicitly restores the moral balance to their interactions with Japanese (Marchetti 127-38).

However, two qualities suggest that the talents behind Sayonara intended to provide some relief within whatever terms that the Motion Picture Production Code could allow, even challenging the Hays Office at certain points. First, as

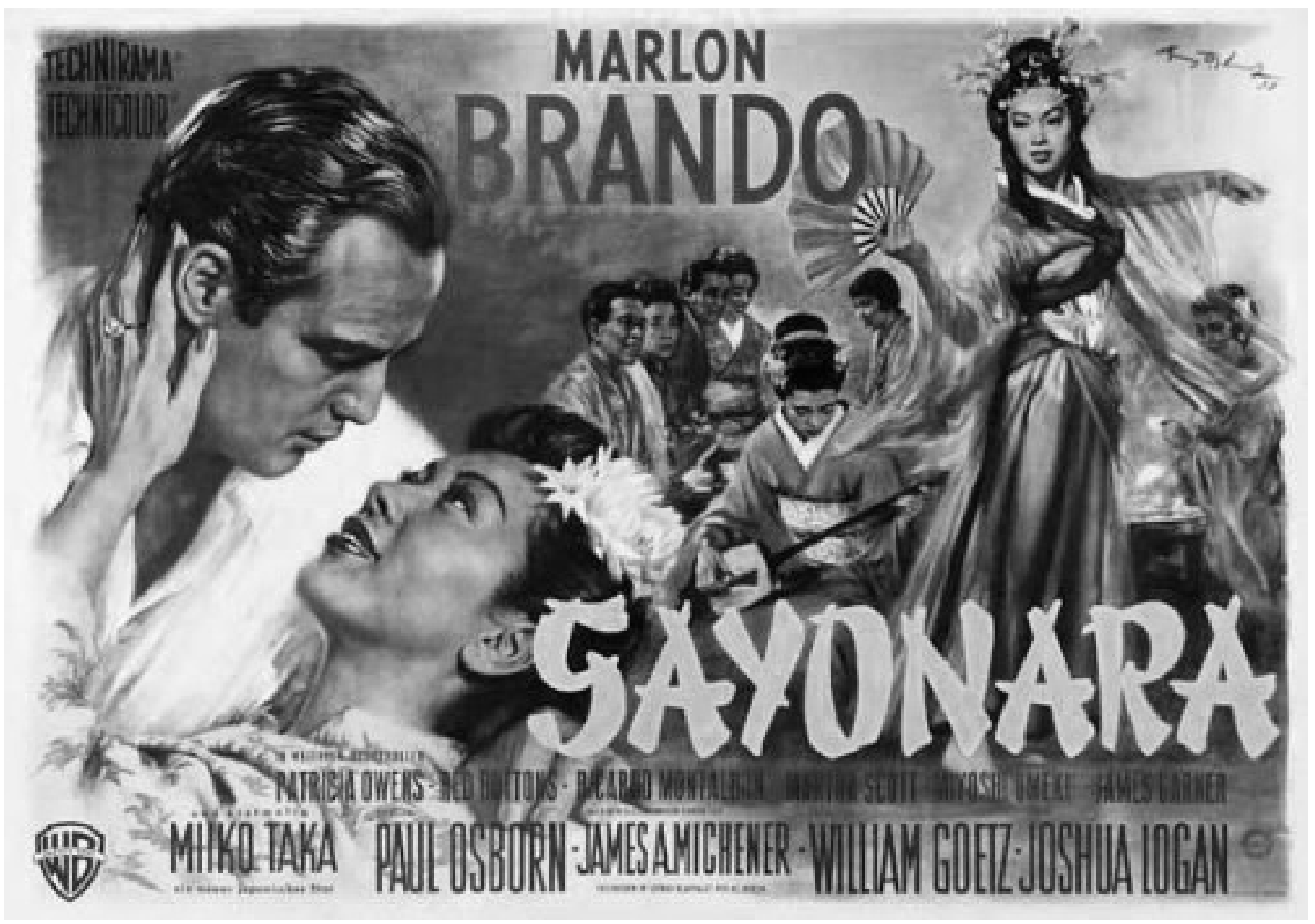

Figure 4. Marlon Brando and Taka Miiko in Joshua Logan's Sayonara (1957). Publicity layout by Pennebaker Productions and William Goetz Productions. 
Marchetti noted, and consistent with The Manchurian Candidate's political scenario, a criticism of McCarthyist witch-hunting is suggested when the US Army makes a list of servicemen living with Japanese women (Marchetti 130) - in fact, the figure of ten thousand servicemen that one officer announces was historically accurate, and one of those persons was James Michener himself; next, the interracially involved men are hunted down and penalized supposedly as random disciplinary targets, but with everyone fully aware of the scandal of miscegenation as the unmentioned actual reason. More than this reference to recent US events, Sayonara depicts not one but a double interracial affair, with the earlier wedded couple deciding to commit suicide due to army prosecution, and the latter couple, Gruver and Hana Ogi, a musical-theater performer who specializes in male roles (thereby appearing at first in men's clothes), finally allowed to look forward to a life of happiness together. The scenes of intimacy between the Caucasian serviceman and his East Asian lover, openly defying social and censorship norms, may have been a first in a Hollywood production of this stature, with a star of the magnitude of Brando.

\section{THE RETURN}

It may be impossible to determine whether this global policy of integration led to the demise of Orientalism as Americans had known it, although we may be more definitively able to ascribe the "model citizen" stature that Asians enjoy (so to speak) in the US to the resultant change in attitude. Up to this point in the history of the Korean War film, we might be able to claim that more liberal, if not critical, images appeared in Hollywood samples, especially in the aforementioned non-combat films. Considering that the cessation of hostilities in Korea did not officially end the war itself, and that the short spell of unstable democratic processes was followed by a comparatively stable military dictatorship, the policing of film content, especially on the Korean War, was not only necessarily but also virtually automatic. In fact one of the earliest censorship cases, over Kang-cheon Lee's 1955 film Piagol [피아골], turned on the question of how sympathetic this combat film was toward North Koreans.

A fallow period for Western films on the Korean War began in the 1980 and persists to the present, and it might be instructive to take a look at the two US productions that purported to feature combat scenes in Korea. Both of these were produced roughly during the centennial of the birth of Douglas MacArthur, as was a magisterial biography, American Caesar, by William Manchester. In 1977, a year before the biography came out, Universal Pictures produced an epic-scale combat film titled MacArthur, directed by Joseph Sargent and starring Gregory Peck. The 
film covers the US Army General's traversal of Australasian territories, from his pullout from Corregidor through his interlude in Australia, following his pushback against Imperial Japanese troops from New Guinea through the Philippines, then with another lull in Japan interrupted by the Korean War, culminating in the muchadmired and intensively studied Incheon coastal-landing maneuver that turned the tide of the war.

The standard MacArthur sagas are significant in that they observe the opposite trajectory of films like Sayonara, King Vidor's Japanese War Bride (1952), and Daniel Mann's The Teahouse of the August Moon (1956). In these Japan-set films, US military service personnel in Japan are understood, whether spelled out or not in the narrative, to be stationed there between or after serving in the Korean War, in much the same way that US military personnel stationed in the Philippines during the '6os through the mid-'7os were assumed to be fighting in the Vietnam War. ${ }^{7}$ In the MacArthur films, the main character necessarily ends his story in Korea, since he was removed from his appointment as Commander of the United Nations forces by President Truman before the truce between the warring parties was finalized (Manchester 766-71). The films were also unabashedly hagiographic and were willing to overlook the several unbiased and less-glamorous analyses of character that Manchester, as an example, proffered. In the case of the 1977 MacArthur, the general even outlines his plans for reoccupying the Philippines and points to Lingayen Gulf as his plan for his first beach landing: the Luzon map resembles the Korean peninsula, with the gulf roughly the place where Incheon would be located-although in actuality MacArthur landed in Leyte, a southern island in the Visayas, rather than in Luzon.

Of greater interest is the MacArthur film that might have been responsible for an overload on heroic filmizations of the life of US generals: Terence Young's Inchon (sospelled), made in 1981, effectively expands the last quarter of MacArthur, covering the time the general spent in Korea and culminating in the Incheon maneuver, where US troops bisected the peninsula, deprived the North Korean army of resources in the south, and came close to retaking the entire national territory of Korea if not for the sudden intervention of the Chinese People's Liberation Army (see Figure 5). The movie attained a high degree of notoriety even before its completion, since it was produced by the late Sun Myung Moon's Unification Church (Segye Pyeonghwa Tong-il Gajeong Yeonhap, literally Family Federation for World Peace and Unification), a right-wing religious denomination accused, among other things, of abducting new members to brainwash them. Inchon itself was regarded as a bigbudget folly, at just under fifty million US dollars the most expensive movie ever made up to that point in history. It won a number of informal "bad movie" prizes and swept the Golden Raspberry Awards, winning the categories for worst movie, 
director, screenplay, and actor. ${ }^{8}$ The movie nevertheless had its share of admirers, most prominently then-US President (and former B-movie actor) Ronald Reagan.

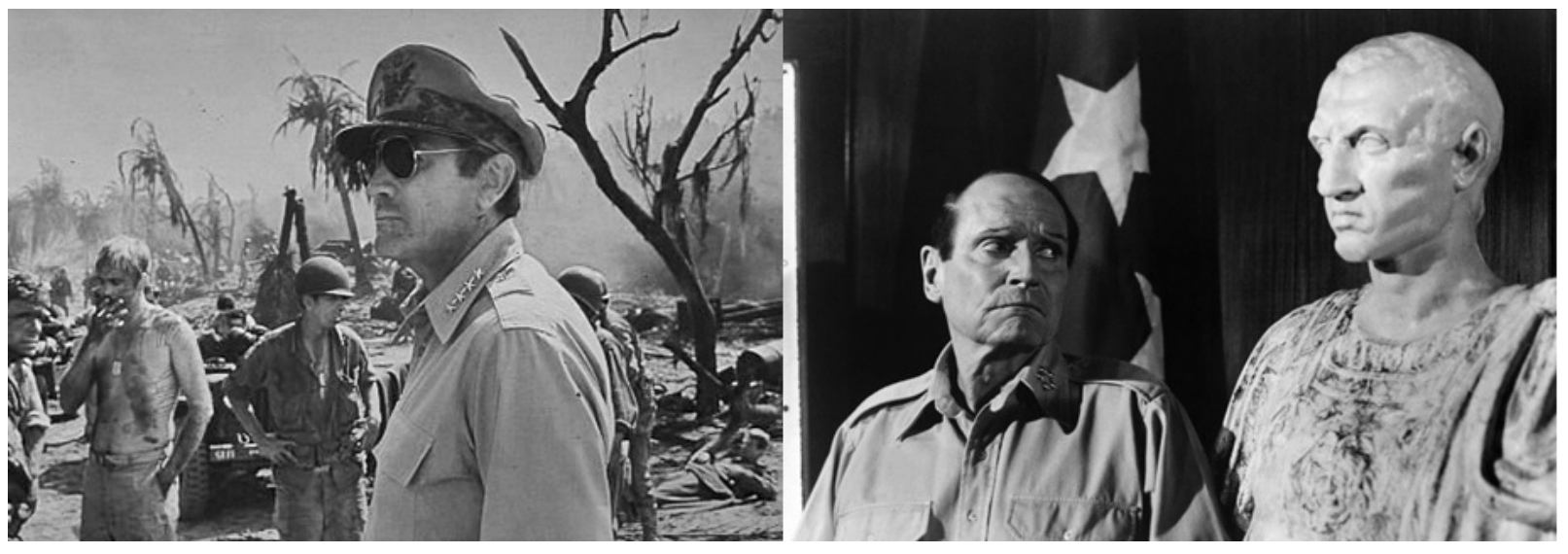

Figure 5. Gregory Peck in Joseph Sargent's MacArthur (1977), left; and Laurence Olivier also as Douglas MacArthur, beside a bust of Julius Caesar, in Terence Young's Inchon (1981). Publicity stills from Universal Pictures; and One Way Productions and Unification Church respectively.

Yet aside from watching what might possibly be Laurence Olivier's all-time worst performance, Inchon provides a historical detail that might seem unusual to any casual onlooker, or even to most students of Korean cinema. During one of the many damsel-in-distress scenes of the leading lady, the wife of one of MacArthur's officers, she and five orphans she picked up on the way get saved by Turkish troops, who escort her and her charges by pulling her station wagon uphill to a religious order's orphanage. One may wonder about the prominent role given to Turkish characters, since Turks constituted only one of twenty-two participating countries under the UN Command and were the most numerous only among the non-First World countries. One could point to the Turkish troops' impressive record in the war (Brockett 140-41), as well as to an apocryphal and ersatz version of history that had two neighboring groups, the GokTurk and the Goguryeo tribes, separated during the sixth century by the Chinese Sui Dynasty; the GokTurks, driven further West, supposedly eventually became the present-day Turks (T.K.).

The interest in Korea among Turks might be even more intense, if we go by contemporary cultural artefacts. ${ }^{9}$ An IMDB search for Korean War movies would yield around ten Turkish titles - a trifling compared to the output of Korea and the 
US, but more than what any other country had made. The Philippines, for example, had only three feature films that most cinephiles are aware of, all produced by LVN Pictures, with two of them directed by Lamberto V. Avellana. One of them, the officially lost Korea (1952), was scripted by Benigno Aquino Jr. (father of the fifteenth [2010-16] President), based on his memoirs as war correspondent, while the other, the neorealist Anak Dalita [Child of Sorrow] (1956), featured a war veteran returning to a life of poverty and strife in the slums of the Walled City of Intramuros; the third, Ulilang Bituin [Orphan Star] (1957), directed by the thenforemost Filipina filmmaker Susana C. de Guzman, was all about a Korean war bride (see Figure 6). In the case of Japan, if we exclude the US productions set in the country, we wind up with almost nothing overtly about the Korean War, unlike the celebrated movie, Ichikawa Kon's Nobi [Fires on the Plain] (1959), on the Japanese occupation of the Philippines; two New Wave-inspired films by Ôshima Nagisa, Yunbogi no nikki [Diary of Yunbogi] (1956) and Kôshikei [Death by Hanging] (1968), respectively criticize the devastation of the Korean War as well as the discriminatory treatment practiced against Korean expatriates in Japan, while a later feature, Yōichi Sai's Tsuki wa dotchi ni dete iru [All under the Moon] (1993), depicts the struggle to survive of the Korean community as well as other nationals, including Filipinas, in contemporary Japanese society. ${ }^{10}$

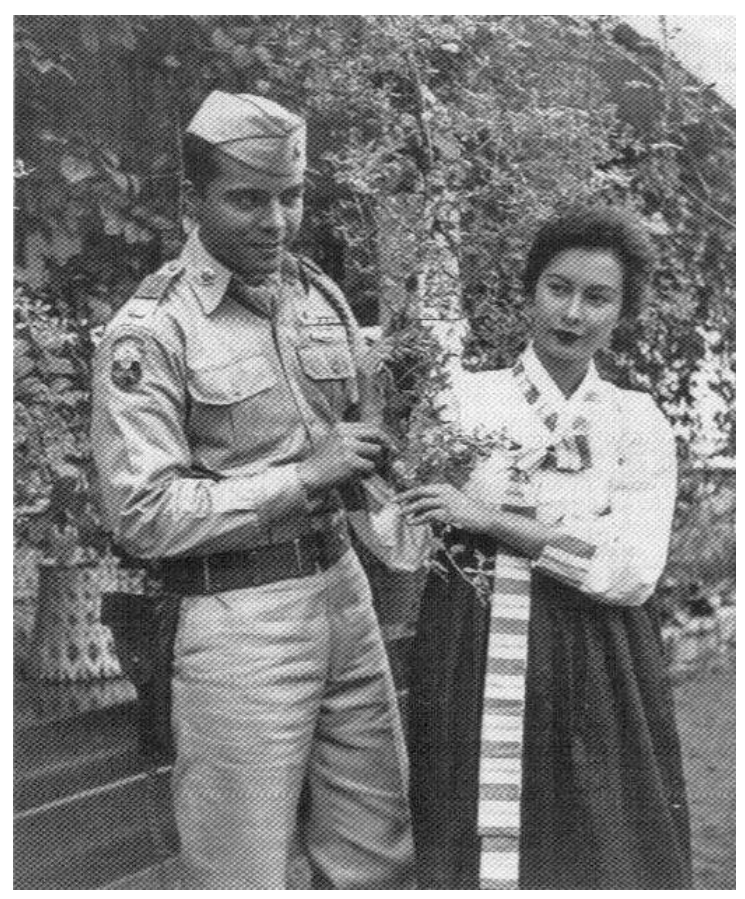

Figure 6. Mario Montenegro as a returning Filipino soldier and Charito Solis as his Korean bride in Susana C. de Guzman's Ulilang Bituin (1957). Publicity still by LVN Pictures. 


\section{NEW KOREAN CINEMA}

Having pointed out that non-Korean films on the Korean War (as opposed to Korean War combat films) deserve a reconsideration in war-film genre studies as the overlooked intermediate stage between Classical Hollywood's World War II approach and the New American Cinema's Vietnam War films, one might be forgiven for thinking that the issue may be closed forthwith. Moreover, after Hollywood's MacArthur-film follies, Korean War film production in Korea followed suit by producing the least number of Korean-War films of any decade, during the 1980 ${ }^{11}{ }^{11}$ In actuality, artistic and narratological innovations in Korean War films revivified after the '8os, even if the only traces we can find in Western films would be, as earlier mentioned, the occasional elderly character reminiscing on his or (occasionally) her memories of the war.

The regularity of renewed production of Korean movies on the Korean War has been so insistent and influential that it may be possible to devise any number of teleological readings based on any kind of arrangement of these films, from chronological to thematic to auteurist and so on, and perhaps even make a claim that no other national cinema has performed as impressively in the depiction of war and its aftermath; this proceeds from the admittedly essentialist qualification that, in contrast, the US's outstanding achievement in the combat-film genre consists of its Vietnam War movies, which at best approximate, and oftentimes leave out, the voice of the primary affected population, the Vietnamese themselves. What follows will be an attempt to provide a reading of certain selected titles, not necessarily comprehensive or even the "best" ones, but those that generated attention among foreign and native Korean film enthusiasts. While the reading may not be definitive, it is close to an idealized imaginary of how far the Korean War movie has progressed from both its local and its global origins.

The renowned elderly filmmaker Kwon-taek Im, after an extensive career that began almost right after the Korean War, and during a late-career run comprising successful blockbusters and festival winners, adapted a ten-volume novel into a nearly three-hour film, Taebaek sanmaek [태백산맥; The Taebaek Mountains] (1994), the second attempt at an adaptation of the novel since Kwon Yeong-sun's 1975 version. Set in a small South Korean village, the material concerns the build-up to the Korean War, with power transferring hands mainly between the extremists of pro-North Communists and US-supported partisans, with civilians forced to choose whichever force is ascendant then getting slaughtered when the other side takes over. Of the four main characters, two represent middle forces-an intellectual (science, via the dialectic between nationalism and feudal land tenureship) and a female shaman (tradition) - while two others are brothers aligned with either political extreme. This last specific element of reluctant yet violent sibling rivalry

Kritika Kultura 28 (2017): -146

(C) Ateneo de Manila University

$<$ http://journals.ateneo.edu/ojs/kk/> 
will continue to persist in succeeding Korean-produced Korean War films, and the role of the woman as a signifier of the past will also occasionally arise as a secondary concern.

Since Taebaek sanmaek broke Im's series of box-office hits, the next significant Korean War film would take some time to be attempted. In 1998, Kwang-mo Lee wrote and directed Areumdawoon sheejul [아름다운 시절; Spring in My Hometown], which positioned its narrative at the opposite temporal point of Im's-i.e., toward the end of the Korean War (see Figure 7). Although the violence in the later film is personalized, it is just as potent and traumatic, involving children who witness poverty and prostitution and who commit arson and matricide. Yet the tone of the film is elegiac, a quality also present in Taebaek sanmaek although often overwhelmed there by Im's operatic depiction of conflict. Also, the protagonists in Areumdawoon sheejul are two childhood friends who bond together so intensely as a result of the war that, like the aforementioned pair in Taebaek sanmaek, their ties become practically fraternal in the end.

Two films after these period treatments situate the question of North-South conflicts in the present (see Figure 8). ${ }^{12}$ Je-kyu Kang's Swiri [쉬리; Shiri] (1999) configures a female double agent as torn between her love for the South Korean agent that she has been assigned to assassinate and the North Korean handler who

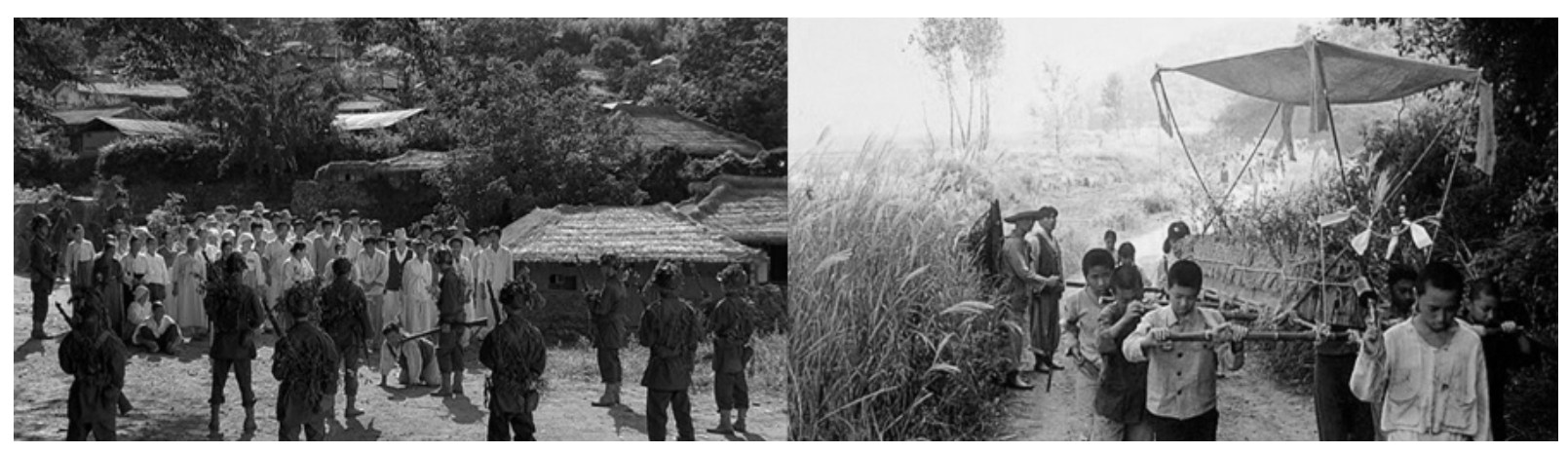

Figure 7. Im Kwon-Taek's Taebaek sanmaek (1994), left; and Lee Kwang-mo's Areumdawoon sheejul (1998), right. Publicity stills from Taehung Pictures and Korean Film Art Center BaekDuDaeGan Company Ltd. respectively.

considers her his protégé. An entire meld of plot twists and devices, including cameras embedded in freshwater fish (the "swiri" of the title) and a heat-activated clear liquid explosive, plus the major characters' near-superhuman expertise with martial arts and weaponry, mark the influence of Hong Kong police-procedural 
action sagas, although once more the use of a female character to embody the conflictive relations between North and South is more of a throwback than a feminist gesture. Another woman conducts an investigation that uncovers the mystery behind a high-profile massacre at the demilitarized zone in Chan-wook Park's Gongdong gyeongbi guyeok JSA [공동경비구역 JSA; JSA: Joint Security Area] (2000). Since the character here is depicted as having grown up abroad and representing a neutral investigating body, she may be seen as a conflation of the two "apolitical" sides (i.e., the intellectual and the shaman) in Taebaek sanmaek. What persists through these films is that when a loyalist North Korean character emerges, he tends to insist on disruptive action, to the detriment of other characters, whether from North or South, who attain a measure of mutual understanding and cooperation. In $J S A$, in fact, the "truth" that the woman investigator uncovers, the scandal that the North Korean side had violently attempted to efface, is that the South Korean soldier who befriended his North Korean counterparts also managed to develop friendships that were in danger of surmounting their ideological differences.

The film that foregrounded and literalized this perspective of the Korean War as an event that resulted in the sundering of masculine bonds was Je-kyu Kang's Taegukgi hwinalrimyeo [태극기 휘날리며; Tae Guk Gi: The Brotherhood of War] (2004). The plot turned on the travails of two brothers, forcibly separated during

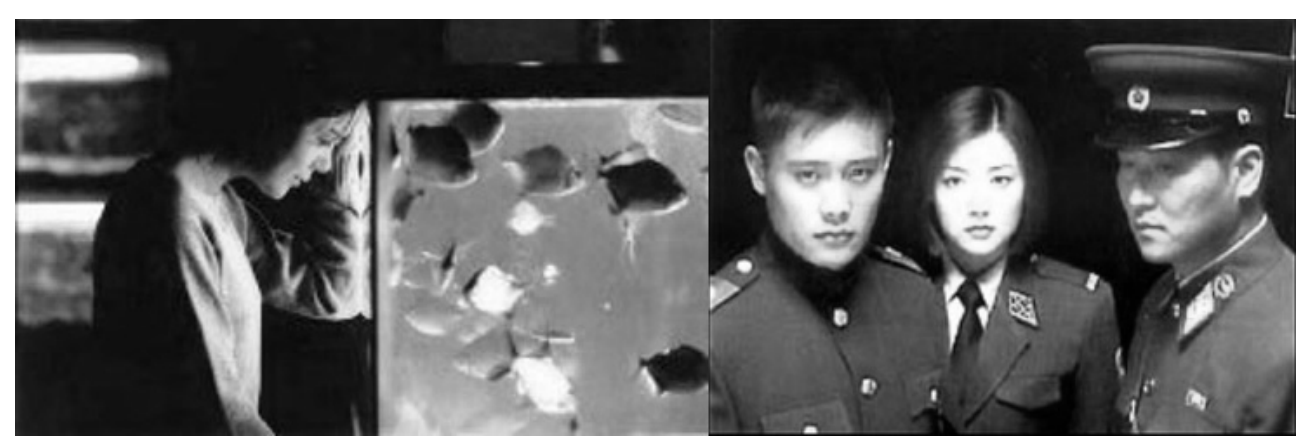

Figure 8. Je-kyu Kang's Swiri (1999), left; and Chan-wook Park's Gongdong gyeongbi guyeok JSA (2000), right. From Kang Je-Kyu Film Co. Ltd. and Samsung Entertainment respectively.

one of the refugee crises induced by the conflict and eventually rediscovering each other as soldiers fighting for opposing sides (see Figure 9). The framing device has the surviving South Korean brother seeking the whereabouts of his North Korean sibling and recalling their separation and mortal confrontation on the battlefield. More than any Korean War film before or since, Taegukgi reconfigures the genre as essentially male melodrama, imbuing the combat scenes with tragic 
melancholy and homosocial romance rather than the life-or-death anxieties that Hollywood combat films usually evoke. ${ }^{13}$ As in the previous Korean War films, the North Korean character is made to embody an ideological fundamentalism that exacerbates the tension between the siblings; this holdover from the earlier Manichean presentations of Communist subjects was to be further tempered in succeeding Korean War film entries.

By way of demonstrating that the concept of Koreans unified by culture although divided by nation was an idea that had arrived, so to speak, in local cinema, a few modest hits from the previous year were already advancing the argument. Joon-ik Lee's Hwangsanbul [황산벌; Once Upon a Time in the Battlefield], set during the

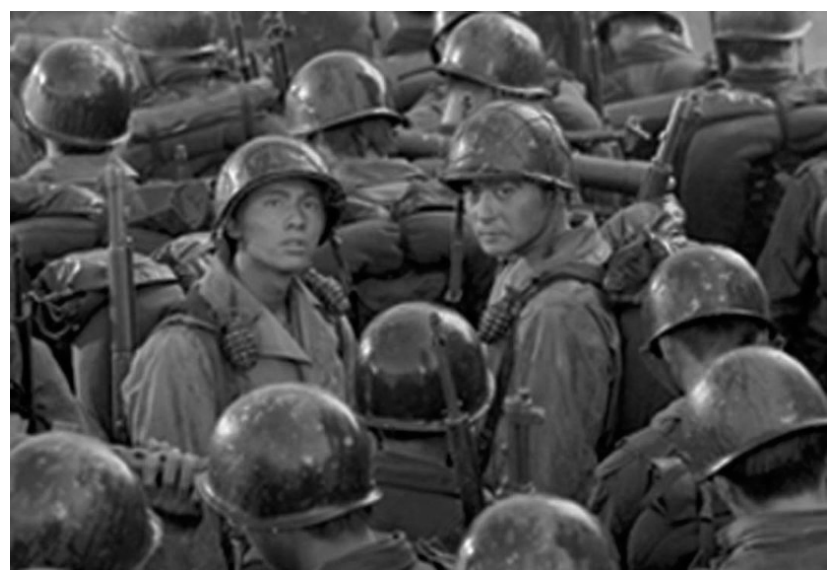

Figure 9. Je-kyu Kang's Taegukgi hwinalrimyeo (2004). Publicity still by Showbox Entertainment and Kang Je-Kyu Film Co. Ltd.

fifth century, has leaders of the three pre-unified kingdoms conspiring against the tribute required by the Chinese empire. In the historically fictive comic treatment, when one of the leaders betrays the other to align with China, the leaders panic and abandon their troops, leaving it up to one of the warriors to lead the battle. A nearly contemporaneous release, Ki-Seon Hong's Seontaek [선택; The Road Taken], concerns the travails of Sun-myung Kim, who had been incarcerated since 1953 for his Communist sympathies and was eventually recognized as the longest-serving political prisoner of his time by Amnesty International, while Hyeon-jeong Kim's Ijung gancheob [이중간첩; Double Agent] provides a more realistic variation on Swiri, with the title character a male defector from North Korea whose resolve to serve his country of birth is shaken after his female handler, with whom he falls in love, begins to doubt the usefulness of their efforts as spies in enemy territory. 
The figure of the woman as an idealization of the nation, tradition, and peacetime re-emerged in the next year's Korean War movie, Kwang-Hyun Park's Battle Ground 625 (2005, US title). Based on a 2002 play by Jin Jang, the movie is actually a speculative fiction whose premise is evoked more directly by its originally Konglish title, Welkkeom tu Dongmakgol [웰컴 투 동막골; Welcome to Dongmakgol] (see Figure 10). Two teams of enemy soldiers wander into an isolated village where an American pilot had earlier crashed. The villagers, usually with a mute natureloving holy-innocent maiden acting as emissary, prevail on them to set aside their differences and coexist as essentially premodern subjects. The return of the US Air Force, whose officers believe that their pilot needs to be rescued, results in the woman getting killed and the North and South Korean soldiers devising, at the cost of their own survival, a plan to divert the US planes' bomb run away from Dongmakgol.

At this point, it can be argued that the Korean-War film has been capable of matching some of the best samples in a Hollywood-dominated genre, alwaysalready admittedly limited by the genre's nationalistic orientation. Where issues of

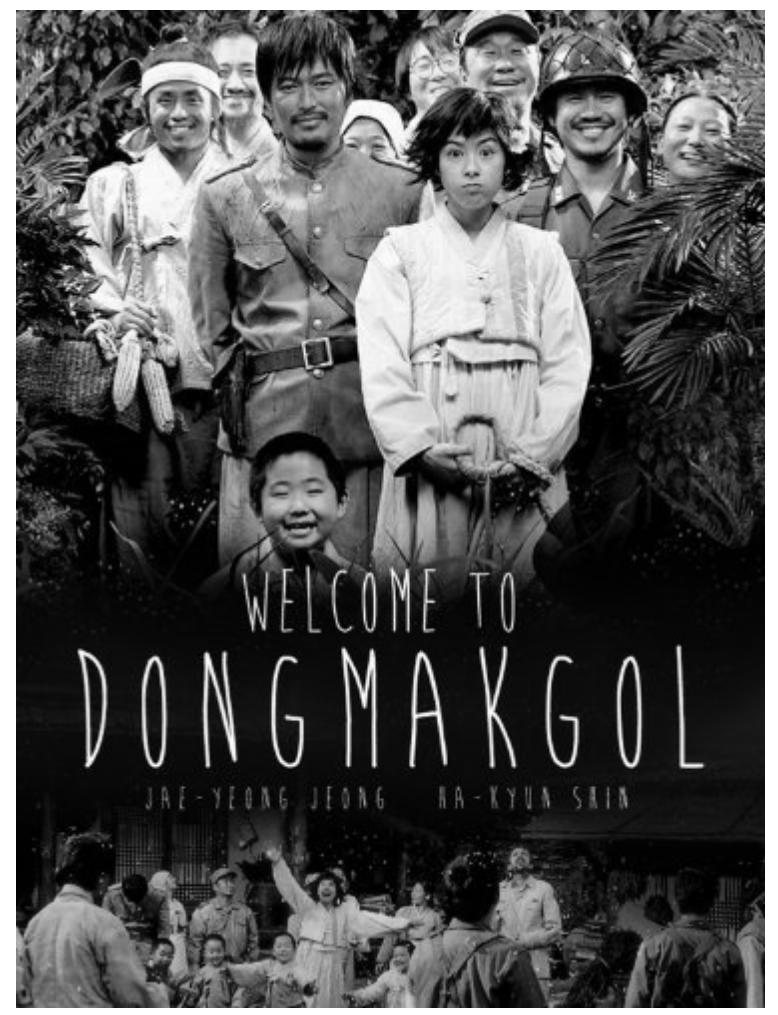

Figure 10. Kwang-Hyun Park's Welkkeom tu Dongmakgol [a.k.a. Battle Ground 625] (2005). Publicity layout by Film It Suda. 
historical accuracy are impossible to resolve, because of the multiplicity of subjective perspectives in such large-scale undertakings, the only ideological issue that may be upheld with relatively minimal problematizing would be that of progressivity, or the question of which agency's version of and perspective on events to privilege. In the succeeding samples, we find that the earlier trend of focusing on ground-level troops as representatives of their respective warring armies persists, but with a finer distinction being drawn between the soldiers and their commanding officers. The ideal of humanist solidarity is invested, regardless of ideological position, in the working-class participants rather than their elite superiors.

\section{RECENT (AND FUTURE) KOREAN WAR FILMS}

The conscious gendering of Korean War protagonists in Korean cinema may be problematized as attempting a means of depathologizing the socialist enemy by suggesting that, on the ground level of enlisted personnel at least, combatants possess sufficient common qualities (usually racial and cultural, including linguistic) to be able to claim virtual kinships. The presence of women, and the reproductive function that they signify (Canto 340), becomes the means of enlightening the participants, ironically by serving as throwbacks to premodern history and tradition. The effect of this rejection of the Cold War injunction to contain an "unacceptable" ideological position succeeds primarily because historically, the orthodox socialist option no longer exists elsewhere, thus rendering North Korea a contemporary historical anomaly. As material proof, these aforementioned Korean War films had been box-office hits (as the following ones have also been), with a few of them attaining the distinction of being all-time blockbusters.

Yet the moment when gender progressivity enters the fray and demands that feminist and queer possibilities be acknowledged may also be around the corner. The Korean War films produced during the 2010s suggest explorations along this line (see Figure 11). Swiri and Taegukgi director Kang's Mai wei [마이 웨이; My Way] (2011) situates its plot during the earlier period of the Japanese occupation and World War II, and makes no effort to qualify its Korean protagonist's Japanese rival as a stand-in for the subsequent North Korean antagonist. Although privileged with class and colonial advantages, the Japanese character first begins to respect his Korean adversary and then openly supports him, to the point where they exchange identities and allow their intertwined stories to explain the historical puzzle of a Korean soldier's body discovered during the D-Day Allied invasion of Normandy. This manner of disavowing the North Korean figure without necessarily providing a South Korean character for contrast was also arguably the motive for depicting the Jeosonjok, or Chinese Koreans, in Hong-jin Na's Hwanghae [황해; The Yellow

Kritika Kultura 28 (2017): -146

(C) Ateneo de Manila University

<http://journals.ateneo.edu/ojs/kk/> 
Sea] (2010). Since this type of character is arguably both Korean and non-South Korean, "afflicted" by a socialist system, and desirous of earning a decent living in South Korea, he could embody both politically conflicted sides in the same character-which is how Hwanghae's protagonist turns out.

The last significant Korean War film before the mid-2010s releases, Hoon Jang's Go-ji-jeon [고지전; The Front Line] (2011), may arguably be the strongest fraternalbonding narrative of the present output, possibly informed with the more liberal

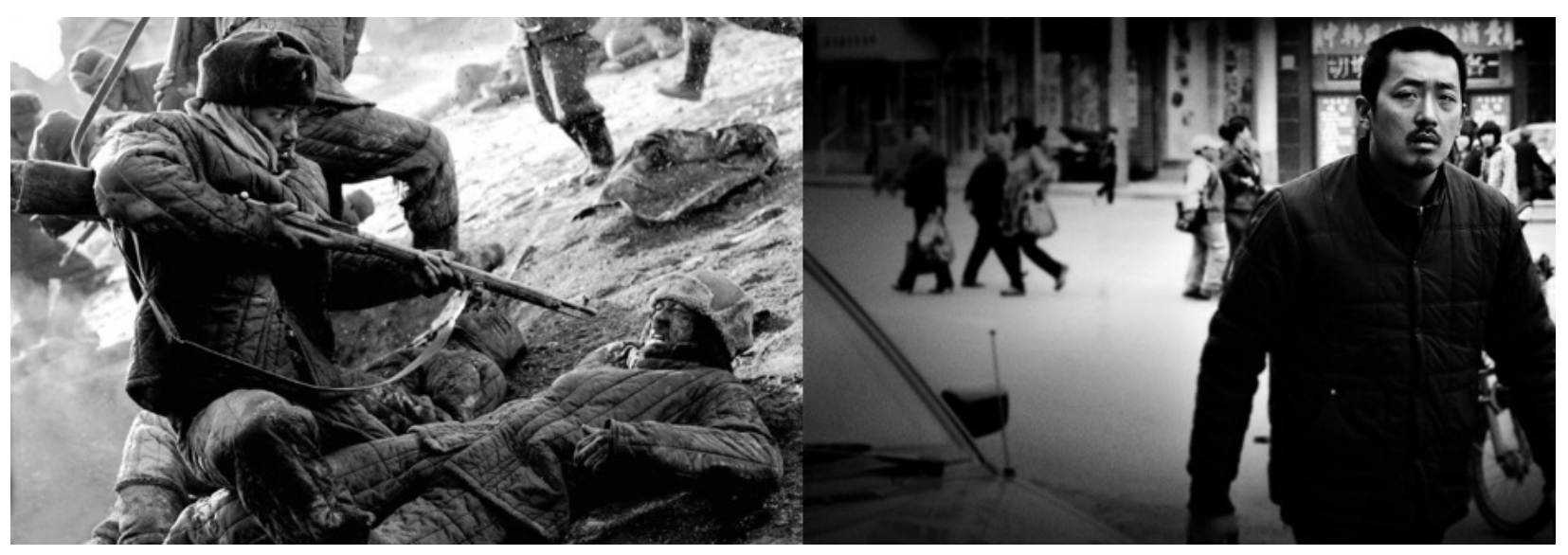

Figure 11. Je-kyu Kang's Mai wei (2011), left; and Hong-jin Na's Hwanghae (2010), right. Publicity stills from Directors, SK Planet, and CJ Entertainment; and Wellmade Starm and Popcorn Films respectively.

depictions of ideological antagonists in the intervening samples, described by an appreciator as "brilliantly [capturing] the absurdity and futility of this cycle of repetition in the present" (Eperjesi). Two units, representing opposing sides, discover an underground bunker during the period of armistice negotiationswhen a ceasefire was supposed to be observed but both sides continued to fight for border areas in order to allow their governments to argue for expanded territories. Since one side and then the other would have exclusive access to the bunker, each side would leave messages, requests, and presents for the other, thus initiating the type of virtual familiarity now regularly practiced by social-network netizens. When the opponents actually meet, they manage to hail one another even as they perform the deadly maneuvers that would result in the annihilation of their others. The leadership of both sides, who secretly insist on continuing hostilities while professing support for the ceasefire, wind up denouncing their own personnel precisely for this suggestion of fraternal empathy with their enemies. 
After Go-ji-jeon, the major Korean entry that dealt with the war, Je-kyoon Yoon's Gukjesijang [국제시장; Ode to My Father] (2014), begins with the Korean War but ends with the present (see Figure 12). Although it has siblings separated by the war, the missing child left in the North is the protagonist's sister, who re-emerges not as a North Korean but as an American adoptee. Deok-soo, the main male character, also has a best friend, but this character is rendered not as a rival but as a sidekick. The "enemy" in the narrative, with whom Deok-soo has to compete and then come to terms, is Korean history, with his trajectory observing the tides of globalization that deluge the less-privileged citizens and wash them up wherever opportunity calls them, sometimes on foreign shores (the Korean title literally translates as "international market"). While we may argue that this portrayal of a benevolent patriarch cannot be automatically tagged as feminist, it may also be noted that Deok-soo is maintained as feminized, or insufficiently patriarchalized, all the way to the end of his story. This open ending to the reading of Korea's Korean War films may yet lead to further breakthroughs in the country's evolution of popular imagery; or it may be overtaken by reunification and result in a further, perhaps transfigured, series of films, based on the final and long-overdue resolution of the war. $^{14}$

After the mid-2010s, at least one significant Korean War film would be released

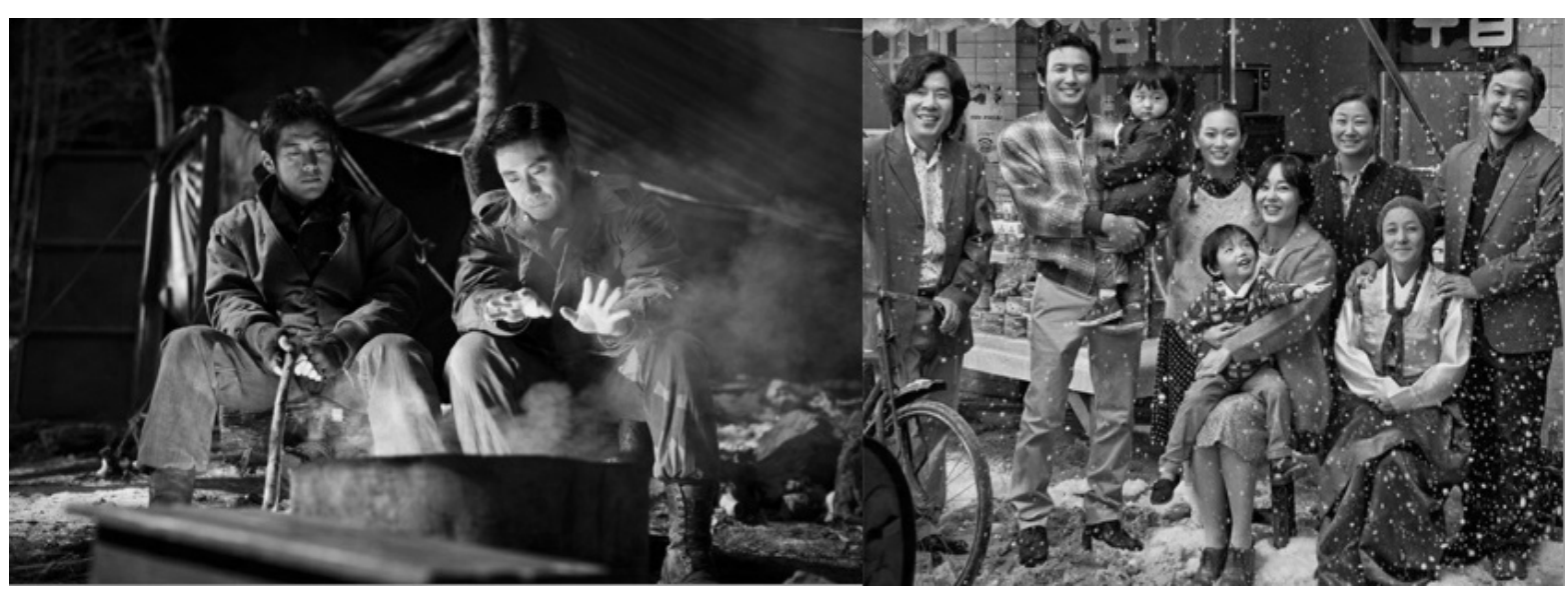

Figure 12. Hoon Jang's Go-ji-jeon (2011), left; and Je-kyoon Yoon's Gukjesijang (2014), right. Publicity stills from TPS Co. and A-Po Films; and JK Films respectively.

per year. In 2015, Kwang-tae Kim's Sonnim [손님; The Piper; literally, The Guest], 
functions as a folkloric parable similar to Welkkeom tu Dongmakgol, but with a critical (in fact demonizing) perspective toward the villagers who insistent on maintaining a premodern system. The same year's other major entry, Song-il Cheon's Seoboojeonsun [서부전선; The Long Way Home], may be the first actual Korean War comedy (inasmuch as MASH was not Korean in origin and intent, and Inchon was only inadvertently funny). The movie enables its hybrid-genre premise to work by confining the scenes to two youthful naïfs, a North Korean tank operator and a South Korean tasked with delivering a top-secret message to US headquarters, isolated from the rest of their comrades; the ultimate irony occurs when their eventual mutual understanding is obliterated by the two warring sides, during the moment when an armistice is declared. In 2016, Han Lee (see endnote 8) made a subsequent post-Korean War tearjerker, Op-pa saeng-gak [오빠 생각; A Melody to Remember, though the title literally translates as Thinking of My Older Brother], based on the true story of a soldier returnee who formed an

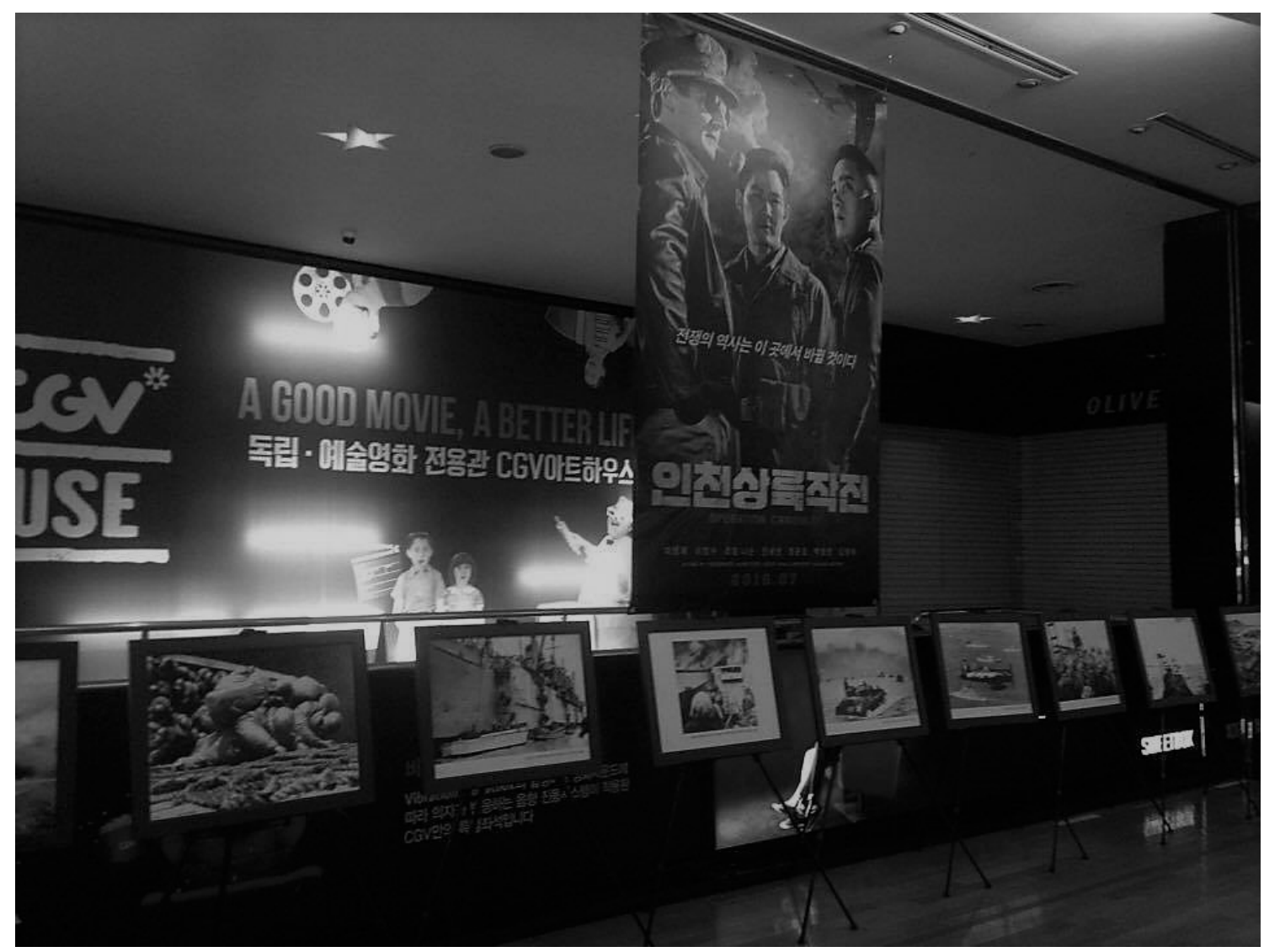

Figure 13. Korean War exhibit for John H. Lee's MacArthur film Incheon sangnyuk jakjeon (2016), at the lobby of the Incheon branch of the CGV theater chain. Photo by the author. 
internationally acclaimed children's choir; part of the film's argument is that the music also served to heal the children's, as well as the choir leader's, war-induced traumas. A so-far final recent sample, John H. Lee's Incheon sangnyuk jakjeon [ 인천상륙작전; Operation Chromite; literally The Battle of Incheon] (see Figure 13), also contributes its own distinction by being the first fairly competent MacArthur film, attaining its dramatic rationale by focusing on the heroism of a South Korean spy in the North Korean army, whose tactical intelligence is deemed crucial in executing the general's Incheon maneuver.

\section{CONCLUSION}

The productivity of Korean cinema in terms of filmic discourses on the Korean War is unique in the history of world cinema, in the specific sense that it enabled Korea to be the only non-European country to lay primary claim to a war-film genre that Hollywood (owing to US participation) first attempted to cover. Korean War films produced in Korea had never really ended, and the country's preoccupation with the conflict is understandable, considering its so-far lack of resolution. The resurgence in Korean War film production can also be ascribed to the success of hallyu, in effectively expanding the market for consumers of expensive pop-culture products.

This last point may be elaborated on further: while hallyu is, on the micro level, definable as any popular Korean cultural product that manages to make an international impact, the Korean War film cannot be readily equated with the several telenovela and K-pop samples that are recognized in households throughout Asia as well as in Latin America and the US. Several of the films discussed in this study definitely enjoyed Korean-blockbuster status, but only the earlier ones (especially the ones where the war is more of historical context than actual subject) might be familiar to global-film enthusiasts. We might speculate that the contemporary resurgence of real-life transnational conflicts could account for a sense of fatigue on the part of the potential audience for war-film material, the same way that film productions on World War II and the Vietnam and Korean wars proliferated only after those events had been resolved. Even if this may be the case, the time lag would still be unusual for the hallyu phenomenon, and may allow us to conclude that: first, the Korean-War film genre, by remaining almost exclusively locally popular at present, is the exception that proves the rule; and second, by thriving within the same historical moment as hallyu, yet being barely perceptible except to hallyu enthusiasts who opt to dig more deeply and resolutely, it enjoys (so to speak) a stature equivalent to the art films of European festival favorites like Sang-soo Hong and Ki-duk Kim. By working out the predicament of big-budget prestige

Kritika Kultura 28 (2017): -146

(C) Ateneo de Manila University

<http://journals.ateneo.edu/ojs/kk/> 
production, where the work has to attain sufficient audience acceptance yet provide discursive novelty and significance, the filmmakers presumably acknowledge the overseas profit potential of hallyu, even if the films remain successful only in a pre-hallyu manner. ${ }^{15}$

What may have been overlooked thus far, among critical observations of Korean cinema, is the discursive wealth achieved by the country's film artists, comparable to (and possibly likely to exceed) Hollywood output on World War II. This may also be explained by an irony in Western-controlled global cinema. Unlike, say, horror or romance, war films (called combat films in this article) are not as commercially viable as when the event still happens to be fairly recent. Hence a Hollywood producer, for example, would be doubly challenged by a Korean War film project in the sense that it would be both a combat film and a period film. Such a problem would be not as magnified for Korean film producers, who have access to sets, scenery, and props, not to mention authentic performers. In this respect, the contemporary Korean-produced Korean War film would not need to worry about competition from the West.

The question, however, of how such a financially risky mode of genre production could subsist in Korea may lie outside the objectives of this project, and will have to be tackled as a separate study focusing this time on cultural policy and political economy. For the moment, we can provide some provisional observations. To balance the drastic liberalization of the Korean screen-quota system enforced by the US-Korea Bilateral Investment Treaty (as a response to the late 1990s Asian financial crisis), the Korean government increased its indirect subsidies in support of infrastructure and distribution channels (Parc 11). Yet the fact that audiences responded favorably enough to encourage further production affirms the overdetermined nature of the practice. An emergent concept of "pockets of resistance" may be derived from certain cultural products (including literature, cuisine, and local-tourist destinations) that may fall under the rubric of the popular, but also furnish the Korean consumer with what we may term insider pleasure, a delight and satisfaction in knowing that the global hallyu audience will not be able to take as readily to these products as the natives could, and do.

A future downswing in Korean War film production might result from the prospective decline in the profitability of hallyu, rather than from a lessened interest of its primary audience, the Korean mass viewers. On the other hand, a further resurgence or renewal might also lie in the genre's future, when the Korean War itself ends and the reunified country embarks on updated accounts of the conflict. As it remains, the Korean experience in its war-film production could also be more intensively studied as a possible sample of indigenizing a "universal" mode of practice, positioning it outside the interests of global competitors, and building 
up on its conventions with a view to attaining liberal and progressive perspectives on the material. 


\section{Acknowledgments}

Assistance for the study was provided by the Inha University Research Grant. The author wishes to acknowledge the support and encouragement of Ju-Yong Ha, Inkyu Park, Sang Hun Lee, Taeyun Yu, Jongsuk Ham, Shin-gu Park, Boemshik Son, Hyunwoo Kim, Farah C. Cunanan, Violeda A. Umali, Lulu Torres-Reyes, Oona Thommes Paredes, Sylvia Claudio Estrada, Caroline Hau, Bliss Cua Lim, Lauren Steimer, Mauro Feria Tumbocon, Ellen Ongkeko-Marfil, Rody Vera, Ibarra Mateo, Sybil Jade Peña, Rochit Tañedo, Theo Pie, Miguel Manansala, and JC Velasquez. Some findings in this paper were first presented by the author in a keynote lecture during the Philippine Korean Studies Symposium in 2015. 


\section{Notes}

1. One more disadvantage of conducting this type of categorically predetermined search is that films on the aftermath of the Korean War get left out. Significant examples would be productions that reference North Korea's supreme leadersSteve Anderson's Dead Men Can't Dance (1997, shot in Korea, with the Philippines representing the North), on Kim Il-sung's regime; Trey Parker's Team America: World Police (2004), on Kim Jong-il; and Evan Goldberg and Seth Rogen's The Interview (2014), on Kim Jong-un. The first is a Rambo-derivative rescue narrative, the second a marionette animation that parodies both Western superheroes and anti-Western "terrorists," and the third is a speculative fiction. Only the last two are intentionally comic and actually represent the Kims in their cast of characters.

2. For a reading of an even more disparate horror sample, the 1968 George Romero zombie film, see Sumiko Higashi's "Night of the Living Dead: A Horror Film about the Horrors of the Vietnam Era."

3. For some samples, see Doherty's Projections of War and Eberwein's The Hollywood War Film. In an earlier cited anthology, Slocum's Hollywood and War, only one of the twenty-six articles (which will be discussed later) deals with the Korean War, Charles Young's “Missing Action." In Tony Day and Maya H.T. Liem's Cultures at War, none of the eleven contributions directly covers the Korean War, despite the fact that several of the countries participated.

4. Aside from Lentz's previously cited Korean War Filmography, other studies would include Paul M. Edwards's A Guide to Films on the Korean War and Theodore Hughes's Literature and Film in Cold War South Korea. The last one also cites in several places a number of dissertations on Korean literature and film, many of which have found or are finding their way to published status. More comprehensive studies would include Coleman's American Images of Korea.

5. See for example Terrence Malick's The Thin Red Line and Steven Spielberg's Saving Private Ryan (both 1998), and Clint Eastwood's Flags of our Fathers and Letters from Iwo Jima (both 2006).

6. Only two years after Sayonara would Western films finally dare to reverse this gendered convention, with the non-white man and white woman exempted from any comeuppance proceeding from their romantic relationship. (Compare these for example with the "yellow" characters' fates in Cecil B. DeMille's The Cheat [1915, re-released 1918] and in D.W. Griffith's Broken Blossoms [1919]: both characters get punished, although the first desired to possess a less-than-upright white woman but was prevented from ravishing her, while the second expressed strictly platonic concern for an abused waif.) Unsurprisingly, it could only be done outside the pale of the Motion Picture Production code. In one instance, a B-movie by Samuel Fuller, titled Crimson Kimono (1959), has a pair of detectives, one Caucasian and the other of Japanese origin, fall in love with the same (white) woman. In France, the French New Wave entry Hiroshima mon amour [Hiroshima My Love] (1959), directed by Alain Resnais and written by Marguerite Duras, went a step further. 
Aside from providing a Japanese man and French woman as lovers, the film also opened with images suggesting the nuclear bombing of the title city (the reason for its exclusion from competition at the Cannes Film Festival - Lanzoni 229), followed by the lovers in a postcoital embrace.

7. A curious exception to this pattern would be Henry King's 1955 film Love Is a ManySplendored Thing, where an American (married but separated) correspondent falls in love with a Chinese residing in Hong Kong during the 1946-50 Communist Revolution in China. Based on Suyin Han's autobiographical novel (where Han is played by Jennifer Jones), the correspondent (William Holden, in his first of two HK-set projects) is deployed by his news agency to cover the Korean War. Han is left alone to deal with the prejudice from relatives and friends that had built up over her cross-racial affair, only to learn that her lover had been killed in Korea. (I am grateful to a peer reviewer for reminding me of the significance of Korea in Han's novel and its film adaptation - a function that resembles the Korean War's "presence" as a traumatizing memory, but also that differs as an impetus for rethinking interracial relations, in the Japan-set US films.)

8. Laurence Olivier, who "won" for his performance, had to endure over two hours of makeup every shooting day (which he admitted was unsuccessful in making him look like MacArthur); he also claimed that he took on the assignment for monetary reasons, as a way of saving up for his retirement: "Nothing is beneath me if it pays well. I've earned the right to damn well grab whatever I can in the time I've got left" - Laurence Olivier, 1979 interview in Rome with Rex Reed for New York Daily News (qtd. in Beckett 134).

9. The attempt to determine any motive for the Turks' intensive interest in the Korean War can only be speculated at this time from the Turkish audience's interest in such topics, including local conflicts with ethnic minorities. Savaş Arslan's excellent recent volume, Cinema in Turkey, has a singular reference to the war, when he describes Yeşilçam (Turkey's Hollywood counterpart) responding "to Turkey's international conflicts with, say, the Korean War or Cyprus conflict films, or to its internal strife through social realist films" (249).

10. For a study of the figure of the Filipina in All under the Moon as well as in Han Lee's Punch (2011), see Taeyun Yu's "Reincarnation of the Pinay Subaltern in Foreign Cinema." The films made by the People's Republic of China may be considered an elaboration on or extension of the type of films made by its ally, North Korea, and so a closer inspection of these will have to be deferred for now. However, a curious Hong Kong - China co-production, made by a Taiwanese filmmaker, T. F. Mou's Men Behind the Sun (1988), portrays the events in the infamous Unit 731, the topsecret laboratory in the Pingfang district in China, which conducted inhumane medical experiments on thousands of Chinese, Korean, Mongolian, Russian, and colonized-Asian subjects, including infants, the elderly, and pregnant women, many of whom died horribly. At the end of the narrative, intertitles explain that when the US accepted the surrender of Japan, it did not investigate the unit for war crimes (upon the recommendation of MacArthur - see Gold 109), and that Lieutenant General Shirō Ishii, appointed by Hirohito as Commander of the euphemistically titled Army Epidemic Prevention Research Library, was later 
spotted in the Korean War front in 1952, allegedly as biological weapons adviser for the US Army. If we observe a liberal typology of the MacArthur film, then Men Behind the Sun, in involving the general and winding up (if only via epilogue) with the Korean War, might be able to occupy a special place after the hagiographic movies already discussed.

11. Kyung Hyun Kim mentions only two feature productions during this decade: Ch'ang-ho Pae's That Winter So Warm (1984) and Kwon-Taek Im's Gilsottum (1986), in "Is This How the War Is Remembered?" (199).

12. More extensive discussions of these four films may be found in Kyung Hyun Kim's The Remasculinization of Korean Cinema; see esp. "Is This How the War is Remembered?" (77-106, for The Taebaek Mountains and Spring in My Hometown) and "Each Man Kills the Thing He Loves" (259-76 for Shiri and JSA). A later movie that, like JSA, attained all-time blockbuster status was Woo-Suk Kang's Silmido (2003), about the tragically botched attempt to train a suicide commando squad to assassinate the North Korean supreme leader. The plot of Ki-duk Kim's The Coast Guard (2002), although confined to a South Korean border patrol team, at one point presents a game of foot-volleyball where a full map of the Korean peninsula is drawn on the ground and the barbed-wire net is drawn over the demilitarized zone on the map-see Yu Taeyun's "Forbidden Pleasure" (30-33).

13. Robin Wood once controversially asserted, in Hollywood from Vietnam to Reagan, that Michael Cimino's The Deer Hunter (1978) was exceptional because of its suggestion of repressed homosexual desire among the protagonists (294). Several critics contested Wood's interpretation as a case of overreading; as an example, see Susan Jeffords's “Reproducing Fathers" (207).

14. Interestingly, the latest all-time Korean blockbuster also came out in 2014, and was also a war film; yet this time, the conflict it referenced was not so much the Korean War as its predecessor, the Japanese occupation and annexation of the peninsula. Han-min Kim's Myeong-ryang [The Admiral: Roaring Currents] was set in the late $16^{\text {th }}$ century, when Joseon dynasty admiral Sun-sin Yi defeated a vastly numerically superior Japanese naval force with only about a dozen of his famed "turtle ships," the world's first armored vessels. One immediate response may have been to take this as an indication that the Korean audience had had Korean-War film fatigue; but the continuing production of the genre since then has disproved this notion.

15. I would like to acknowledge the unexpectedly serendipitous insights provided by another anonymous peer reviewer, which enabled me to expound on the idea of the Korean War movie as a hallyu-yet-not-quite product. 


\section{Works Cited}

Arslan, Savaş. Cinema in Turkey: A New Critical History. Oxford UP, 2011.

Beckett, Francis. Olivier. Haus Publishing, 2005.

Brockett, Gavin D. "The Legend of 'The Turk' in Korea: Popular Perceptions of the Korean War and Their Importance to a Turkish National Identity." War \& Society, vol. 22, no. 2, October 2004, pp. 109-42.

Canto, Monique. “The Politics of Women's Bodies: Reflections on Plato." Trans. Arthur Goldhammer. The Female Body in Western Culture: Contemporary Perspectives, edited by Susan Rubin Suleiman, Harvard UP, 1985, pp. 339-53.

Coleman, Craig S. American Images of Korea: Korea and Koreans as Portrayed in Books, Magazines, Television, News Media, and Film. Hollym International, 1990.

Day, Tony, and Maya H.T. Liem, eds. Cultures at War: The Cold War and Cultural Expression in Southeast Asia. Southeast Asia Program Publications, 2010.

Deocampo, Nick. Film: American Influences on Philippine Cinema. Vol. 2 of Reflections on One Hundred Years of Cinema in the Philippines series. Anvil, 2011.

Dittmar, Linda, and Gene Michaud. From Hanoi to Hollywood: The Vietnam War in American Film. Rutgers UP, 1990.

Doherty, Thomas. Projections of War: Hollywood, American Culture, and World War II. Rev. ed. Columbia UP, 1999.

Eberwein, Robert. The Hollywood War Film. Wiley-Blackwell, 2010.

Edwards, Paul M. A Guide to Films on the Korean War. Greenwood, 1997.

Eperjesi, John R. "From Pork Chop Hill to The Front Line: Peace as a Korean Human Right." Huffington Post, 20 Apr. 2014. Web. Accessed 12 Jan. 2016.

Esthus, Raymund A. “The Taft-Katsura Agreement: Reality or Myth?” Journal of Modern History, vol. 31, no. 1, March 1959, pp. 46-51.

Gold, Hal. Unit 731 Testimony. Tuttle, 1996.

Higashi Sumiko. "Night of the Living Dead: A Horror Film about the Horrors of the Vietnam Era." From Hanoi to Hollywood: The Vietnam War in American Film, edited by Linda Dittmar and Gene Michaud, Rutgers UP, 1990, pp. 175-88.

Hughes, Theodore. Literature and Film in Cold War South Korea: Freedom's Frontier. Columbia UP, 2012.

Jeffords, Susan. "Reproducing Fathers." From Hanoi to Hollywood: The Vietnam War in American Film, edited by Linda Dittmar and Gene Michaud, Rutgers UP, 1990, pp. 203-16.

Kim Kyung Hyun. "Is This How the War Is Remembered? Deceptive Sex and the Remasculinized Nation in The Taebaek Mountains." Im Kwon-Taek: The Making of a Korean National Cinema, edited by David E. James and Kim Kyung Hyun, Wayne State UP, 2002, pp. 197-222.

- The Remasculinization of Korean Cinema. Duke UP, 2004.

Klein, Christina. Cold War Orientalism: Asia in the Middlebrow Imagination, 1945-1961. U of California P, 2003. 
Lanzoni, Remi Fournier. French Cinema: From Its Beginnings to the Present. Continuum International, 2004.

Lenin, V. I. "Directives on the Film Business [dictated 17 Jan. 1922]," Kinonedelya 4 (1925), trans. Bernard Isaacs. Lenin Internet Archive, 2003. Web. Accessed 10 Aug. 2015.

Lentz, Robert J. Korean War Filmography: 91 English Language Features through 2000. McFarland, 2003.

Lim, Bliss Cua. "American Pictures Made by Filipinos." Spectator, vol. 22, no. 1, Spring 2012, pp. 23-45.

Manchester, William. American Caesar: Douglas MacArthur, 1880-1964. Dell, 1978.

Marchetti, Gina. Romance and the "Yellow Peril": Race, Sex, and Discursive Strategies in Hollywood Fiction. U of California P, 1993.

Neale, Steve. "War Films." Hollywood and War: The Film Reader, edited by J. David Slocum, Routledge, 2006, pp. 23-30.

Parc, Jimmyn. "The Effects of Protectionism in Cultural Industries: The Case of the Korean Film Policies." International Journal of Cultural Policy, 2016, pp. 1-16.

Sklar, Robert. Movie-Made America: A Cultural History of American Movies. Vintage, 1994.

Slocum, J. David. "General Introduction: Seeing Through American War Cinema."

Hollywood and War: The Film Reader, edited by J. David Slocum, Routledge, 2006, pp. 1-22. Print.

T.K. [The Korean], "What Do Koreans Think about Turkey?” Ask a Korean, April 2014. Web. Accessed 20 Aug. 2015.

Wood, Robin. Hollywood from Vietnam to Reagan. Columbia UP, 1986.

Wu, Ellen D. The Color of Success: Asian Americans and the Origins of the Model Minority. Princeton UP, 2014.

Young, Charles. "Missing Action: POW Films, Brainwashing and the Korean War, 19541968." Hollywood and War: The Film Reader, edited by J. David Slocum, Routledge, 2006, pp. 207-24.

Yu Taeyun, "Forbidden Pleasure: A Critical Reappreciation of Korean Sadomasochistic Cinema." University of the Philippines unpublished thesis, 2009.

--. "Reincarnation of the Pinay Subaltern in Foreign Cinema." Kritika Kultura, vol. 21-22, August 2013 \& February 2014, pp. 584-610. 